PRZEGLĄD RUSYCYSTYCZNY

2019, nr 3(167)

\author{
НАТАЛЬЯ ЛУНЬКОВА \\ НАДЕЖДА СТАРИКОВА \\ ЕВГЕНИЯ ШАТЬКО
}

Институт славяноведения Российской академии наук

\title{
РОМАН МАСТЕР И МАРГАРИТА: ТРУДНОСТИ ПЕРЕВОДА СОВЕТСКИХ РЕАЛИЙ (НА ПРИМЕРЕ ЮЖНОСЛАВЯНСКИХ ЯЗЫКОВ)
}

Роман Михаила Афанасьевича Булгакова Мастер и Маргаpuта вот уже более полувека привлекает внимание мировой читательской аудитории, подтверждая известную мысль Гидеона Тури о том, что «культура прибегает к переводу как к основному способу заполнения лакун, где бы и когда бы подобные лакуны ни обнаруживали себя - либо сами по себе, либо (чаще всего) с компаративной точки зрения, то есть с учетом соответствующего явления в другой культуре, на которое у принимающей культуры есть повод равняться и которое есть смысл использовать» ${ }^{1}$ Устойчивый интерес к этому произведению сохраняется и в славянских странах, где регулярно переиздаются его классические переводные версии и выходят новые, например, в Болгарии (2012) и Польше (2016). Большинство первых переводов романа на славянские языки появлялось «по горячим следам» - после советской публикации 1967 г. и франкфуртской 1969 г.: в 1968 г. - на болгарский, сербский и словацкий языки, в 1969 г. - на чешский, польский и хорватский, в 1970 г. - на македонский и в 1971 г. - на словенский язык. Текстологическим материалом для данной статьи послужили четыре перевода на южнославянские языки (болгарский, сербский, хорватский, словенский), каждый из которых по-своему представляет национальный переводческий канон своего времени. Во всех издани-

1 G. Toury, Descriptive Translation Studies - and beyond // «Benjamins Translation Library» 1995, № 4, с. 27. Пер. авторов статьи. 
ях присутствуют ошибки, текстуальные искажения, смещения смысловых акцентов, в первую очередь связанные с недостаточным владением переводчиками и редакторами историческим, литературным, социокультурным и «писательским» контекстом произведения, в том числе знанием специфики быта и «предметов материальной и духовной культуры, отражающих образ жизни и образ мышления ${ }^{2}$ жителей советской Москвы. Есть надежда, что выявление ряда «узких» мест при перенесении советских реалий в иноязычное пространство поможет при выборе дальнейших переводческих стратегий, ибо роман Булгакова во все времена будет оставаться в центре внимания читателей, а значит, будет сохраняться потребность в его новом прочтении. Недостатки, обнаруженные авторами статьи при анализе переводов, ни в коем случае не умаляют той роли, которую роман Maстер и Mаргарита продолжает играть как «катализатор» интереса к русской литературе, они лишь доказывают, сколь непростая задача встает перед каждым переводчиком булгаковского текста. Именно благодаря таким произведениям «переводная литература органически включается в эволюционный процесс отечественной литературы, в определенной степени восполняет недостаток отечественного эволюционного потенциала и тем самым наиболее выразительно осуществляет свою функцию связующего звена между литературами» ${ }^{3}$.

Первыми переводчиками Мастера и Маргариты на сербский, хорватский и словенский языки были профессиональные филологи Милан Чолич (1934-2016), Вида Флакер (1935-2007) и Янез Градишник (1917-2009). Чолич, входивший в Ассоциацию сербских литературных переводчиков (UKPS), работал с чешским и русским языком (произведения Богумила Грабала и Михаила Булгакова), много переводил для театра. Флакер хорватский историк литературы, в 1964-1999 гг. работала в Институте истории хорватской литературы, театра и музыки ХАНИ, переводила с русского и немецкого. Градишник - писатель, публицист, член Международной федерации переводчиков (FIT), за перевод Улисса Джеймса Джойса был удостоен высшей национальной переводческой премии Антона Совре (1967). Нет сомне-

2 Н.А. Мороз, Адекватная передача реалий русской культуры в художественном переводе // «Молодой ученый» 2015, № 15, с. 53.

3 Д. Дюришин, Теория сравнительного изучения литератур, пер. И.А. Богдановой, Прогресс, Москва 1979, с. 128. 
ний, что опыт и уровень их мастерства в целом соответствовал грандиозности поставленной задачи: дать вторую жизнь произведению писателя, творчество которого восходит к «генетическим корням европейской культуры»4. До настоящего времени все три перевода считаются в Сербии, Хорватии, Черногории, Боснии и Герцеговине ${ }^{5}$ и Словении ${ }^{6}$ каноническими и регулярно переиздаются. В Болгарии первый перевод Maсmера и Mаргариты сделала в 1968 г. Лиляна Минкова (1932-2016), выдающаяся болгарская переводчица с русского, украинского и французского языков. В 2012 г. вышел второй перевод, выполненный Татьяной Баловой (род. 1953): в ее послужном списке Илья Ильф и Евгений Петров, Борис Акунин, Дина Рубина, Виктор Пелевин др., за перевод Двенадцати стульев Балова была удостоена премии Союза переводчиков Болгарии. При сравнительном анализе текстовых примеров будет использоваться новый болгарский перевод.

Сложность художественной структуры романа, соединение в нем нескольких культурных и историко-религиозных традиций, стилистических и языковых пластов, пропущенных через сатирический, гротескный быт московский жизни 1930-х гг., его «запрограммированность» на двойственную интерпретацию, соединяющую культурный «инстинкт» читателя с необходимостью «отречься» от стереотипов 7 , ставит перед переводчиками весьма трудную задачу. Для носителей языка восприятие художественного произведения подкрепляется в целом естественным знанием своей культуры и феноменов, с ней связанных; у представителя иной культуры возникают определенные трудности с пониманием этого же художественного произведения при прочтении его на родном языке. Так возникает проблема

4 Ю.М. Смирнов, Театр и театральное пространство в романе М.А. Булгакова «Мастер и Маргарита» // Михаил Булгаков: «Этот мир мой...», т. 1, РИИИ, Санкт-Петербург 1993, с. 145.

5 См. Е.В. Шатько, Специфические «советские» и русские реалии в переводах романа «Мастер и Маргарита» (на материале переводов В. Флакер и М. Чолича) // Михаил Булгаков и славянская культура, ред. Е.А. Яблоков, Совпадение, Москва 2017, с. 54.

${ }^{6}$ См. Н.Н. Старикова, Реалии советской Москвы в словенском переводе романа «Мастер и Маргарита» (к проблеме контекста) // Михаил Булгаков и славянская культура..., с. 41.

7 Е.А. Яблоков, Комментарии [к роману «Мастер и Маргарита»] // М.А. Булгаков, Собрание сочинений, АСТ, Москва 2007-2011, т. 7, с. 565. 
точности, но не дословности перенесения всех нюансов текста оригинала на иностранный язык, которая, на наш взгляд, для романа Maстер и Маргарита не может быть преодолена в полной мере. Одним из необходимых условий хотя бы частичного ее решения является владение историческим, литературным и социокультурным контекстом произведения, в том числе знание специфики быта и реалий советской Москвы как места действия и места создания произведения. При этом под реалиями понимаются слова и словосочетания, называющие предметы, явления, объекты, характерные для жизни, быта и культуры москвичей первых десятилетий советской власти, мало знакомые или совсем незнакомые иностранному читателю. Подобные слова несут в себе национальный и временной колорит и, как правило, не имеют точных соответствий в других языках, поэтому требуют особого подхода при переводе. С учетом того, что булгаковский роман изобилует так называемыми лакунами - «ситуациями, обычными для культуры одного народа, но не наблюдаемыми в другой культуре» ${ }^{8}$, его восприятие абсолютно невозможно без соответствующих пояснений. Отсутствие примечаний переводчика и разъясняющих комментариев часто может свести на нет всю «архетипическую», ассоциативную, подтекстовую и даже эмоциональную нюансировку мысли Булгакова, исказить, а иногда полностью нивелировать смысл фразы оригинала. К сожалению, далеко не все рассматриваемые переводы снабжены необходимым справочным аппаратом, что в итоге сказывается на качестве восприятия булгаковского текста.

\begin{tabular}{|l|l|l|l|}
\hline Язык & Переводчик & \multicolumn{1}{|c|}{ Перевод } & $\begin{array}{l}\text { Справочный ап- } \\
\text { парат }\end{array}$ \\
\hline сербский & М. Чолич & $\begin{array}{l}\text { M.A. Bulgakov Majstor } \\
\text { i Margarita, Minerva, } \\
\text { Beograd-Subotica 1968, } \\
\text { c. 352 }\end{array}$ & $\begin{array}{l}\text { Послесловие } \\
\text { переводчика } \\
\text { Заметка о писа- } \\
\text { теле }\end{array}$ \\
\hline $\begin{array}{l}\text { хорват- } \\
\text { ский }\end{array}$ & В. Флакер & $\begin{array}{l}\text { M.A. Bulgakov, Majstor } i \\
\text { Margarita, Naprijed, Za- } \\
\text { greb 1969, c. 394 }\end{array}$ & $\begin{array}{l}\text { Предисловие } \\
\text { Константина Си- } \\
\text { монова }\end{array}$ \\
\hline
\end{tabular}

8 И.И. Ревзин, В.Ю. Розенцвейг, Основы общего и машинного перевода, Высшая школа, Москва 1964, с. 184. 
РОМАН МАСТЕР И МАРГАРИТА...

\begin{tabular}{|l|l|l|l|}
\hline $\begin{array}{l}\text { словен- } \\
\text { ский }\end{array}$ & Я. Градишник & $\begin{array}{l}\text { M.A. Bulgakov, Mojster } \\
\text { in Margareta, Cankarjeva } \\
\text { založba, Ljubljana 1971, } \\
\text { c. 468 }\end{array}$ & $\begin{array}{l}\text { Предисловие } \\
\text { Веры Брнчич }\end{array}$ \\
\hline $\begin{array}{l}\text { болгар- } \\
\text { ский }\end{array}$ & Т. Балова & $\begin{array}{l}\text { М.А. Булгаков, Maйстора } \\
\text { Маргарита, с бележки } \\
\text { и коментари, Дамян Яков, } \\
\text { София 2012, с. 496 }\end{array}$ & $\begin{array}{l}\text { Примечания } \\
\text { и комментарии } \\
\text { редционной } \\
\text { коллегии и пере- } \\
\text { водчика }\end{array}$ \\
\hline
\end{tabular}

Для передачи реалий московского быта переводчики использует описательный, уподобляющий и контекстуальный переводы, а также транслитерацию и калькирование.

\begin{tabular}{|c|c|c|}
\hline Оригинал & Перевод & Значение перевода \\
\hline \multirow[t]{2}{*}{ самокрутка } & $\begin{array}{l}\text { Словен.: } \\
\text { cigareta, ki si jo sam zvil }\end{array}$ & $\begin{array}{l}\text { сигарета, которую скручива- } \\
\text { ешь }\end{array}$ \\
\hline & $\begin{array}{l}\text { Бола.: } \\
\text { който си беше свил цигара }\end{array}$ & $\begin{array}{l}\text { который сам себе скрутил си- } \\
\text { гарету (скрученная сигарета) }\end{array}$ \\
\hline \multirow[t]{3}{*}{ балык } & $\begin{array}{l}\text { Словен.: } \\
\text { sušen jesetrov hrbet }\end{array}$ & сушеная спинка осетра \\
\hline & $\begin{array}{l}\text { Серб.: } \\
\text { dimljena kečiga }\end{array}$ & $\begin{array}{l}\text { копченый осетр из Каспийско- } \\
\text { го моря }\end{array}$ \\
\hline & $\begin{array}{l}\text { Болг.: } \\
\text { едра бяла риба }\end{array}$ & судак \\
\hline \multirow[t]{4}{*}{ нарзан } & $\begin{array}{l}\text { Словен.: } \\
\text { kavkaška slatina }\end{array}$ & кавказская минеральная вода \\
\hline & $\begin{array}{l}\text { Серб.: } \\
\text { kisela voda }\end{array}$ & минеральная вода \\
\hline & $\begin{array}{l}\text { Xорв.: } \\
\text { Narzan }\end{array}$ & $\begin{array}{l}\text { Дано со сноской «целебная } \\
\text { минеральная вода» }\end{array}$ \\
\hline & $\begin{array}{l}\text { Болг.: } \\
\text { нарзан }\end{array}$ & калька без пояснения \\
\hline
\end{tabular}

9 О качестве комментария к данному изданию романа см. подробнее: Н.А. Лунькова, Проблема переводческого комментария (на примере перевода романа «Мастер и Маргарита» на болгарский язык) // Михаил Булгаков и славянская культура..., с. 63-72. 
Н. ЛУНЬКОВА, Н. СТАРИКОВА, Е. ШАТЬКО

\begin{tabular}{|c|c|c|}
\hline \multirow[t]{3}{*}{ папаха } & $\begin{array}{l}\text { Словен.: } \\
\text { kavkaška kučma }\end{array}$ & кавказская меховая шапка \\
\hline & $\begin{array}{l}\text { Серб.: } \\
\text { каvkaska šubara }\end{array}$ & $\begin{array}{l}\text { кавказская «шубара» (серб- } \\
\text { ский меховой головной убор) }\end{array}$ \\
\hline & $\begin{array}{l}\text { Болг.: } \\
\text { кавказки калпак }\end{array}$ & $\begin{array}{l}\text { кавказский меховой колпак } \\
\text { (высокая шапка) }\end{array}$ \\
\hline \multirow[t]{3}{*}{ нефтелавка } & $\begin{array}{l}\text { Словен.: } \\
\text { prodajaljna kurilnega olja }\end{array}$ & магазин мазута \\
\hline & $\begin{array}{l}\text { Серб.: } \\
\text { prodavnica petroleja }\end{array}$ & магазин керосина \\
\hline & $\begin{array}{l}\text { Болг.: } \\
\text { дюкянчето за наливен газ }\end{array}$ & магазин/лавка газа/керосина \\
\hline \multirow{4}{*}{$\begin{array}{l}\text {...в боль- } \\
\text { шом шести- } \\
\text { этажном } \\
\text { доме, } \\
\text { по ко м м } \\
\text { располо- } \\
\text { женном на } \\
\text { Садовой } \\
\text { улице }{ }^{10} .\end{array}$} & $\begin{array}{l}\text { Словен.: } \\
\text {...v veliki petnadstropnici, } \\
\text { obrnjeni v podobi ciril- } \\
\text { skeg a velikega p na } \\
\text { Vrtno ulico }{ }^{11}\end{array}$ & $\begin{array}{l}\text {...в большом шестиэтажном } \\
\text { доме, повернутом в форме } \\
\text { большой кириллической бук- } \\
\text { вы «П» на Садовую улицу. }\end{array}$ \\
\hline & $\begin{array}{l}\text { Серб.: } \\
\text {...velika petospratnica, što } \\
\text { pokojem odnosno } \\
\text { otvorenom stranom } \\
\text { ćirilskog slova "P" } \\
\text { beše okrenuta prema } \\
\text { Sadovoj ulici' }{ }^{12} \text {. }\end{array}$ & $\begin{array}{l}\text { большое шестиэтажное зда- } \\
\text { ние, которое покоем, то есть } \\
\text { открытой частью кирилличе- } \\
\text { ской буквы «П», выходило на } \\
\text { Садовую улицу. }\end{array}$ \\
\hline & $\begin{array}{l}\text { Болг.: } \\
\text {...в голямата шестетажна } \\
\text { сграда, раз п оложена } \\
\text { н а бук в ата «П» на ули- } \\
\text { ца «Садовая» }{ }^{13} \text {. }\end{array}$ & $\begin{array}{l}\text { в большом шестиэтажном зда- } \\
\text { нии, расположенном буквой П } \\
\text { на Садовой улице. }\end{array}$ \\
\hline & $\begin{array}{l}\text { Хорв. } \\
\text { velika peterokatnica okre- } \\
\text { nuta na Sadovu ulicu }{ }^{14}\end{array}$ & $\begin{array}{l}\text { большое шестиэтажное зда- } \\
\text { ние, выходящее на Садовую } \\
\text { улицу }\end{array}$ \\
\hline
\end{tabular}

${ }^{10}$ М.А. Булгаков, Собрание сочинений, т. 7..., с. 91.

${ }^{11}$ M.A. Bulgakov, Mojster in Margareta, Cankarjeva založba, Ljubljana 1971, c. 78.

${ }^{12}$ M.A.Bulgakov, Majstor i Margarita, IP Book, Beograd 2009, c. 114.

${ }_{13}$ М.А. Булгаков, Майстора и Маргарита, Дамян Яков, София 2012, с. 86.

${ }^{14}$ M.A. Bulgakov, Majstor i Margarita, Andromeda, Rijeka 1993, c. 82. 


\begin{tabular}{|c|c|c|}
\hline \multirow[t]{4}{*}{$\begin{array}{l}\text { торгсин на } \\
\text { Смоленском } \\
\text { рынке }\end{array}$} & $\begin{array}{l}\text { Словен.: } \\
\text { trgovina za tujce na Smolen- } \\
\text { skem trgu }\end{array}$ & $\begin{array}{l}\text { магазин для иностранцев на } \\
\text { Смоленской площади }\end{array}$ \\
\hline & $\begin{array}{l}\text { Хорв.: } \\
\text { Torgsin - со сноской } \\
\text { «Trgovina s inozemstvom; } \\
\text { dućan gdje se prodavala } \\
\text { inozemna roba samo za } \\
\text { stranu valutu»15. }\end{array}$ & $\begin{array}{l}\text { торговля с заграницей; ма- } \\
\text { газин, где продавались ино- } \\
\text { странные товары только за } \\
\text { иностранную валюту }\end{array}$ \\
\hline & $\begin{array}{l}\text { Серб.: } \\
\text { Torgsin } \\
\end{array}$ & транслитерация курсивом \\
\hline & $\begin{array}{l}\text { Болг.: } \\
\text { валутен магазин на Смо- } \\
\text { ленския пазар }\end{array}$ & $\begin{array}{l}\text { валютный магазин на Смолен- } \\
\text { ском рынке }\end{array}$ \\
\hline
\end{tabular}

Предложенные варианты перевода аббревиатуры торгсин, образованной от названия Всесоюзного объединения по торговле с иностранцами, - и описательный («trgovina za tujce», «валутен магазин»), и с помощью транслитерации в целом соответствует действительности. Первоначально торгсинами называли специальные магазины для иностранцев, где торговля шла на валюту и куда советские граждане не допускались. Затем, однако, ситуация изменилась, и москвичи, имеющие «валютные ценности» (золото, серебро, драгоценные камни, предметы старины, наличную валюту), тоже получили право обменять их на продукты питания или дефицитные потребительские товары. В числе постоянных покупателей торгсинов были, как отмечают в комментарии к роману Ирина Белобровцева и Светлана Кульюс, «ювелиры и зубные врачи, получатели крупных переводов из-за границы, иностранцы и спекулянты» ${ }^{16}$. «Сиреневый гражданин», получивший после провокации Коровьева подносом по голове от «приличнейшего тихого старичка» ${ }^{17}$, скорее всего спекулянт, прикинувшийся иностранцем, или агент «органов», следящий за гостями столицы и подпольными советскими миллионерами. Таким образом, одной точной расшифровки словасокращения недостаточно, чтобы понятие «торгсин» как реалия

15 Там же, с. 370.

${ }^{16}$ И. Белобровцева, С. Кульюс, Роман «Мастер и Маргарита»: комментарий, Argo, Таллинн 2006, с. 350.

17 М.А. Булгаков, Собрание сочинений, т. 7..., с. 427. 
советской жизни 1930-х гг. полноценно прозвучало в тексте перевода. Без соответствующих пояснений весь скрытый трагизм этого, на первый взгляд, балаганного эпизода остается вне поля зрения читателя.

Для уподобляющего перевода подбирается функциональный эквивалент, вызывающий у читателя перевода ассоциации, сходные с теми, которые возникают у читателя оригинала.

\begin{tabular}{|c|c|c|}
\hline Оригинал & Перевод & Значение перевода \\
\hline \multirow[t]{4}{*}{ лихач } & $\begin{array}{l}\text { Словен: } \\
\text { кос̌ijaž }\end{array}$ & извозчик \\
\hline & $\begin{array}{l}\text { Хорв.: } \\
\text { fijakerist }\end{array}$ & возница фиакра \\
\hline & $\begin{array}{l}\text { Сеpб.: } \\
\text { kočijaš }\end{array}$ & извозчик \\
\hline & $\begin{array}{l}\text { Болг.: } \\
\text { файтонджия }\end{array}$ & извозчик \\
\hline \multirow[t]{4}{*}{ фабрика-кухня } & $\begin{array}{l}\text { Словен.: } \\
\text { javna kuhinja }\end{array}$ & общественная кухня \\
\hline & $\begin{array}{l}\text { Хорв.: } \\
\text { tvornica-kuhinja }\end{array}$ & фабрика-кухня \\
\hline & $\begin{array}{l}\text { Сepб.: } \\
\text { „fabrika-kuhinja“ }\end{array}$ & фабрика-кухня (в кавычках) \\
\hline & $\begin{array}{l}\text { Болг. } \\
\text { фабрика кухня }\end{array}$ & $\begin{array}{l}\text { фабрика-кухня (калька без } \\
\text { пояснения) }\end{array}$ \\
\hline \multirow[t]{4}{*}{ богомаз } & $\begin{array}{l}\text { Словен.: } \\
\text { mazač }\end{array}$ & пачкун / шарлатан \\
\hline & $\begin{array}{l}\text { Хорв.: } \\
\text { ikonopisac }\end{array}$ & иконописец \\
\hline & $\begin{array}{l}\text { Сеpб: } \\
\text { ništavilo }\end{array}$ & ничтожество \\
\hline & $\begin{array}{l}\text { Бола.: } \\
\text { нескопосан иконописец }\end{array}$ & $\begin{array}{l}\text { неискусный, плохой иконо- } \\
\text { писец }\end{array}$ \\
\hline \multirow[t]{2}{*}{ застройщик } & $\begin{array}{l}\text { Словен.: } \\
\text { stavbenik }\end{array}$ & строитель \\
\hline & $\begin{array}{l}\text { Xорв.: } \\
\text { graditelj }\end{array}$ & строитель \\
\hline
\end{tabular}




\begin{tabular}{|l|l|l|}
\hline & $\begin{array}{l}\text { Серб.: } \\
\text { građevinski preduzimač }\end{array}$ & строительный подрядчик \\
\cline { 2 - 3 } & $\begin{array}{l}\text { Болг.: } \\
\text { строителен предприемач }\end{array}$ & $\begin{array}{l}\text { строительный подрядчик/ } \\
\text { застройщик }\end{array}$ \\
\hline абрикосовая & $\begin{array}{l}\text { Словен.: } \\
\text { marelčni sok }\end{array}$ & абрикосовый сок \\
\cline { 2 - 3 } & $\begin{array}{l}\text { Хорв.: } \\
\text { sok od marelica }\end{array}$ & сок из абрикосов \\
\cline { 2 - 3 } & $\begin{array}{l}\text { Серб.: } \\
\text { sok od kajsija }\end{array}$ & сок из абрикосов \\
\cline { 2 - 3 } & $\begin{array}{l}\text { Болг.: } \\
\text { кайсиев сок }\end{array}$ & абрикосовый сок \\
\hline
\end{tabular}

Удивительно, но именно «абрикосовая» оказалась одним из «заколдованных мест», все переводчики допустили ошибку при переводе воспроизведении диалога героев с продавщицей киоска «Пиво и воды»:

- Дайте нарзану, - попросил Берлиоз.

- Нарзану нету, - ответила женщина в будочке и почему-то обиделась.

- Пиво есть? - сиплым голосом осведомился Бездомный.

- Пиво привезут к вечеру, - ответила женщина.

- А что есть? - спросил Берлиоз.

- Абрикосовая, только теплая, - сказала женщина.

- Ну, давайте, давайте, давайте!... ${ }^{18}$.

Газированная вода с абрикосовым сиропом во всех переводах превращается в абрикосовый сок (натуральный сок в розлив ситуация для советской Москвы немыслимая), который скисает на жаре, иначе откуда берется «обильная желтая пена» ${ }^{19},-$ однако Берлиоз и Бездомный с жадностью утоляют этим сомнительным напитком жажду.

Другим уязвимым местом оказался головной убор председателя правления МАССОЛИТа Берлиоза, который, беседуя с Бездомным на Патриарших, «свою приличную шляпу пирожко м нес в руке» ${ }^{20}$. То есть его головной убор имел особенность формы - глубокую продолговатую впадину на тулье, напоминающую след от пирожка. В словенском и сербском переводах особенность фасона шляпы подменяется способом ее держать:

\footnotetext{
18 Там же, с. 8.

19 Там же.

${ }^{20}$ Там же, с. 7.
} 
«Svoj čedni klobuk je nosil v roki kakor pogačo» ${ }^{21}$ (свою приличную шляпу нес в руке, как пирожок); «d ržaše šešir ka o lepinju» ${ }^{22}$ (держа шляпу как булку); в хорватском и болгарском эта булгаковская деталь вообще опускается: «lagano savijen elegantni šešir» ${ }^{23}$ (слегка изогнутая элегантная шляпа), «държеше хубавата си мека шапка в ръка» ${ }^{24}$ (держал в руке свою красивую мягкую шляпу).

Иногда уподобляющий перевод комбинируется с контекстуальным, то есть заменой словарного соответствия контекстуальным, которое логически с ним связано, это встречается при переводе некоторых фразеологизмов. Доктору Стравинскому, пришедшему осмотреть поэта Бездомного, коллега подает записанный на листе бумаги анамнез. “ЦЦелое дело сшили !' - подумал Иван» ${ }^{25}$. Это выражение, имеющее значение «возводить напраслину, обвинять без оснований», безусловно, восходит к уголовному жаргону, но при переводе нередко теряет свой арго-компонент. Так словенский вариант «'Koliko se tega n a č ečkali’ je pomislil Ivan» ${ }^{26}$ буквально означает: «Сколько они тут всего понаписали». В хорватском “'Napravili su cijeli d o s ij e!' - pomislio je Ivan» ${ }^{27} /$ “'Сделали целое досье’ - подумал Иван» и сербском “'Čitav su dosije uspeli da sklepaju!' - pomisli Ivan ${ }^{28} /$ «Целое досье смогли/успели собрать» утрачено стилистически окрашенное «сшили». Лишь в болгарском переводе «'Цяло дело са ми скалъпили”'29! - помисли си Иван» ${ }^{0}$ жаргонизм сохранен.

Важнейший пласт московской жизни 1920-1930-х гг., где отдельная квартира была роскошью, - коммуналки и их быт. Не зря же Воланд замечает, что москвичей испортил «квартирный вопрос» ${ }^{31}$. Булгаков представляет в романе целую галерею обра-

\footnotetext{
${ }^{21}$ M.A. Bulgakov, Mojster in Margareta ..., c. 37.

${ }^{22}$ M.A. Bulgakov, Majstor i Margarita..., 2009, c. 31.

${ }^{23}$ M A. Bulgakov, Majstor i Margarita ... 1993, c. 9.

${ }^{24}$ М.А. Булгаков, Майстора и Маргарита ..., с. 9.

${ }_{25}$ М.А. Булгаков, Собрание сочинений..., т. 7, с. 107.

${ }^{26}$ M.A. Bulgakov, Mojster in Margareta ..., c. 127.

${ }^{27}$ M.A. Bulgakov, Majstor i Margarita ...1993, c. 96.

${ }^{28}$ M.A. Bulgakov, Majstor i Margarita...2009, c. 130.

29 Болг. «скальпвам» разг., прен. - 1) делать быстро, без старания; стряпать, лепить, шить; 2) выдумывать, фабриковать.

${ }^{30}$ М.А. Булгаков, Майстора и Маргарита ..., с. 101.

${ }^{31}$ М.А. Булгаков, Собрание сочинений..., т. 7, с. 152.
} 
зов обитателей коммуналок, помещает действие одной из сюжетных линий в коммунальную квартиру номер 50, мастер гордится двумя своими отдельными комнатками, нанятыми у застройщика, Маргарита вдвоем с мужем живет в «очаровательном месте», на верхнем этаже особняка, расположенного в арбатских переулках, воплощая мечту миллионов граждан об отдельной жилплощади, Никанор Иванович Босой получает тридцать два заявления, авторы которых претендовали на площадь покойного Берлиоза, дядю Берлиоза, Поплавского, несмотря на сомнительную телеграмму, гонит в Москву желание «хотя бы временно прописаться в трех комнатах покойного племянника»32. Донести подтекст этих обстоятельств московского житья до любого иностранного читателя без комментария довольно затруднительно.

По замыслу большевиков жилищная проблема решалась быстро и без существенных экономических затрат путем передела собственности: «Взять все, да и поделить»33. Коммунальная организация жизни (одна кухня на всех и использование прихожей как места общего пользования) не только была неизбежной в условиях послереволюционного дефицита жилья, но и полностью отвечала требованиям новой социально-политической системы. Вынужденное соседство чужих людей на одной территории стало частью коммунального быта. Проживание в коммунальной квартире порождало массовое соглядатайство и доносительство, к середине 1930-х гг. в коммуналках сложились система бытового поведения, закрепленная в «Правилах внутреннего распорядка», и своя властная иерархия. По сути, коммунальная квартира не выполняла главную функцию городского жилища - защиту приватной жизни и дифференциации приватной и публичных сфер. Все эти особенности, даже детально изученные и понятые переводчиком, при перенесении в иное культурное пространство требуют дополнительных разъяснений. Например, перебранка двух соседок по коммуналке, свидетельницей которой становится путешествующая на щетке Маргарита:

Все окна были открыты, и всюду слышалась в окнах радиомузыка. Из любопытства Маргарита заглянула в одно из них. Увидела кухню. Два примуса ревели на плите, возле них стояли две женщины с ложками в руках и переругивались.

32 Там же, с. 239.

${ }^{33}$ М.А. Булгаков, Собрание сочинений..., т. 2, с. 231. 
- Свет надо тушить за собой в уборной, вот что я вам скажу, Пелагея Петровна, - говорила та женщина, перед которой была кастрюля с какойто снедью, от которой валил пар, - а то мы на выселение на вас по да ди м!

- Сами вы хороши, - отвечала другая.

- Обе вы хороши, - звучно сказала Маргарита, переваливаясь через подоконник в кухню. Обе ссорящиеся повернулись на голос и замерли с грязными ложками в руках ${ }^{34}$.

\section{Словен.:}

Tu so bila vsa okna odprta in skozi vsa je bilo slišati radijsko glasbo. Iz radovednosti je Margareta pogledala skozi eno od njih. Videla je kuhinjo. Na plošči sta šumela dva špiritna gorilnika, zraven njuju sta stali dve ženski z žlicama v rokah in se zmerjali.

«Na stranišču mora človek ugasiti luč za seboj, tako vam povem, Pelageja Petrovna», je govorila ženska, pred katero je stala kozica z neko jedjo, iz katere se je kadila para. «Sicer vas bomo tožili, da se boste morali izseliti» (подадим на вас в суд, чтобы вам пришлось съехать).

«Vi niste sami nič boljši», je odgovorila druga.

«Nobena izmed vaju ni nič prida», je zveneče rekla Margareta in se prevalila čez okensko polico v kuhinjo. Prepirljivki sta se ob glasu obrnili in odereveneli $\mathrm{z}$ umazanima žlicama $\mathrm{v}$ rokah $^{35}$.

Хорв.:

Na njima si svi prozori bili otvoreni i posvuda se u prozorima čula radioglazba. Iz znatiželje, Margarita je pogledala u jedan od njih. Spazila je kuhinju. Dva primusa su tutnjila na štednjaku, kraj njih su stajale dvije žene sa žlicama u rukama i svađale se.

- Svjetlo u zahodu treba za sobom ugasiti, kažem vam, Pelageja Petrovna - govorila je žena pred kojom je stajao lonac s nekakvim jelom s kojeg se dizala para - inače ćemo vas tužiti pa neka vas isele (иначе мы на вас нажалуемся и пусть вас выселят).

- I vi ste mi pametni - odgovarala je druga.

- Obje ste pametne - glasno je rekla Margarita nagnuvši se kroz prozor u kuhinju.

Obje svađalice okrenule su se u smjeru glasa i ukočile se s prljavim žlicama u rukama ${ }^{36}$.

\section{Серб.:}

Svi prozori na njima su bili širom otvoreni, i svuda se iz tih prozora čula muzika iz radio-aparata. Margarita je iz čiste radoznalosti zavirila u jedan od tih prozora. Ugledala je kuhinju. Dva su plinska gorionika hučala na štednjaku, a kraj njih su stajale dve žene sa varjačama u rikama i međusobno se prepucavale.

- Svetlost treba gasiti za sobom u nužniku, moliću lepo, eto šta ću vam reći, Pelagija Petrovna, - govorila je žena, pred kojom se nalazila šerpa sa nekakvim

${ }^{34}$ М.А. Булгаков, Собрание сочинений, т.7..., с. 286.

35 M.A. Bulgakov, Mojster in Margareta ..., c. 286.

${ }^{36}$ M.A. Bulgakov, Majstor i Margarita...1993, c. 254. 
jelom iz kojeg se dizala para - jer ćemo inače zatražiti da vas isele (иначе мы потребуем, чтобы вас выселили).

- A i vi ste mi pa nekakva cvećka - odgovorila joj je ona druga.

- Obe ste cvećke - naglas reče Margarita, preskočevši ragastov i ušavši u kuhinju.

Obe žene koje su se svađale se okrenuše i zamreše na mestu sa prljavim varjačama u rukama ${ }^{37}$.

Болг.:

Всички прозорци бяха отворени и отвред се чуваше да свири радио. От любопитство Маргарита надникна през един от тях. Видя кухня. Върху печката бучаха два примуса, до тях с лъжици в ръцете стояха две жени и се дърлеха.

- Като излизате от клозета, ще гасите лампата, това искам да ви кажа, Пелагея Петровна - говореше жената пред вдигналата пара тенджера с някаква манджа, - инак ще подадем молба да ви преместят друг а де! (иначе мы подадим заявление, чтобы вас переселили в другое место).

- Вие пък сте една стока... - отговори другата.

- И двете сте една стока - звучно каза Маргарита, прехвърли се през перваза и влезе в кухнята.

Двете скандалджийки се обърнаха натам, откъдето идваше гласът, и се вцепениха с мръсните лъжици в ръцете ${ }^{38}$.

Для носителя другой культуры, не знакомого с особенностями жилищной политики советской власти и коммунальным укладом, скрытая подоплека склоки остается непонятной: почему одна соседка по квартире может предъявлять другой столько претензий, да еще и грозить выселением. Чтобы происходящее на коммунальной кухне не осталось для иностранного читателя загадкой, здесь также нужен комментарий, которого - увы! - нет. Как нет его и к эпизоду, когда Иван Бездомный в погоне за свитой Воланда тоже попадает в коммунальную квартиру:

Иван Николаевич [...] тут же зачем-то очутился на кухне. В ней никого не оказалось, и на плите в полумраке стояло безмолвно около десятка потухших примусов. Один лунный луч, просочившись сквозьпыльное, годами не вытираемое окно, скупо освещал тотугол, где в пыли и паутине висела забытая икона, изза киота которой высовывались концы двух венчальных свечей. Под большой иконой висела пришпиленная маленькая - бумажная.

${ }^{37}$ M. A. Bulgakov, Majstor i Margarita ...2009, c. 310.

${ }^{38}$ М. А. Булгаков, Майстора и Маргарита..., с. 268. 
Никому не известно, какая тут мысль овладела Иваном, но только, прежде чем выбежать на черный ход, он присвоил одну из этих свечей, а также и бумажную иконку 39.

\section{Словен.:}

Ivan Nikolajevič [...] se na lepem znašel v kuhinji. V njej ni bilo nikogar; n a plošči ognjišča je v poltemi molče stalo kakih deset ugaslih petrolejskih gorilnikov. En sam lunin žarek, ki se prebilskozi prašno, že leta nepomito okno, je skopo razsvetljeval ogel, kjer je v prahu in pajčevinah visela pozabljena ikona, izza njene omarice pa sta štrlela konca dveh poročnih sveč. Pod veliko ikono je bila z iglo pripeta manjša, papirnasta.

Nihče ne ve, kakšna misel je tedaj obšla Ivana, vsekakor si je, preden je stekel v črno vežo (черные сени), prisvojil eno izmed the dveh sveč in tudi papirnato ikono ${ }^{40}$.

\section{Хорв.:}

Ivan Nikolajevič [...] našao se odmah u kuhinji. U njoj nije bilo nikoga a na štednjaku je stajalo bešumno (бесшумно) u polumraku deset ugaslih primusa. Jedan mjesečev tračak, probivši se kroz prašni, godinama neoprani prozor, škrto je osvjetljavao tajkut gdje je u prašini i paučini visila zaboravljena ikona iza koje su virili vršci dviju voštanica. Ispod velike ikone je pribodena mala ikona od papira.

Nikome nije poznato kakva je misao tada ovladla Ivanom, ali prije nego što će potrčati u crni hodnik (черный коридор), on je prisvojio jednu od svijeća, a isto tako i papirnu ikonu ${ }^{41}$.

\section{Серб.:}

Ivan Nikolajevič [...] najednom se nađe u kuhinji. U njoj ne beše nikoga, a n a plotni štednjaka u polumraku beše desetak ugašenih primusa. Jedan mesečev zrak, probivši se kroz prašnjav, godinama neopran prozor, jedva da je osvetljavao ugao, u kome je u paučini visila ikona, koju je bog zna kada i ko tu zaboravio, i iza kiota su virile dve venčane sveče. Pod velikom ikonom je pribadačom bila zakačena mala - papirna ikonica.

Niko ne može znati šta je u tom trenutku pomislio Ivan, ali je, pre nego što će istrčati iz stana kroz s p or e d a n izlaz (служебный выход), prisvojio jednu od tih sveća i papirnu ikonicu ${ }^{42}$.

Боле.:

Иван Николаевич [...] внезапно се озова в кухнята. Там нямаше никого, само върху печката в полумрака стояха десетина безмълвни загасени примуса. Един лунен лъч, проникнал през прашния, с години немит прозорец, бледо осветяваше ъгъла, където

\footnotetext{
${ }^{39}$ М.А. Булгаков, Собрание сочинений..., т. 7, с. 63.

${ }^{40}$ M.A. Bulgakov, Mojster in Margareta ..., c. 86.

${ }^{41}$ M.A. Bulgakov, Majstor i Margarita ...,1993, c. 6.

${ }^{42}$ M.A .Bulgakov, Majstor i Margarita ..., 2009, c. 86.
} 
сред прах и паяжини висеше забравена икона, а иззад иконостаса се подаваха върховете на две венчални свещи. Под голямата икона беше закачена друга, по-малка, хартиена.

Кой знае каква мисъл бе хрумнала на Иван, та преди да изскочи през задния вход (задний вход), да задигне едната от свещите, а същото и книжната иконка ${ }^{43}$.

В данном случае перевод везде максимально приближен к оригиналу, детали обстановки, характерной для советской коммунальной квартиры, переданы достаточно точно. Однако читателю, не знакомому с переменами, произошедшими в жизни москвичей после революции, едва ли будет понятно, почему на одной кухне стоит десяток примусов, почему окно «пыльное, годами не вытираемое», почему иконы забыты в углу и покрыты паутиной. Здесь важны не только точность перевода, но и воспроизведение духа времени, передать который без ссылки на историко-культурный контекст едва ли возможно. Отдельного внимания заслуживает не столько словосочетание, сколько само понятие «черный ход». В первые годы советской власти оно приобрело новое значение. Доходные дома в Москве имели две лестницы: парадную и «черную», которые служили средством социального разграничения входящих (прислуга могла пользоваться только «черным ходом»). После революции рабочие и крестьяне, вселившиеся в старые «буржуазные» квартиры, наделили черный ход функциями парадного. Так что пролетарский поэт Бездомный устремляется к черному ходу отнюдь не случайно.

Не менее сложны при перенесении на иностранный язык сцены, где в контексте московских культурных реалий присутствуют отсылки к прошлому и настоящему русской и советской литературы. Такова встреча «Сашки-бездарности» Рюхина с «металлическим человеком», то есть с памятником Пушкину на Тверском бульваре, что' понятно русскому читателю, но отнюдь не столь очевидно для тех, кто читает перевод.

Рюхин поднял голову и увидел, что они уже в Москве [...] и что близехонько от него стоит на постаменте металлический человек, чуть наклонив голову, и безразлично смотрит на бульвар.

Какие-то странные мысли хлынули в голову заболевшему поэту. «Вот пример настоящей удачливости... - тут Рюхин встал во весь рост на плат-

${ }^{43}$ М.А. Булгаков, Майстора и Маргарита..., с. 61. 
форме грузовика и руку поднял, нападая зачем-то на никого не трогающего чугунного человека, - какой бы шаг он ни сделал в жизни, что бы ни случилось с ним, все шло ему на пользу, все обращалось к его славе! Но что он сделал? Я не понимаю... Что-нибудь особенное есть в этих словах: ‘Бур я м гл о ю...’? Не понимаю!... Повезло, повезло! - вдруг ядовито заключил Рюхин и почувствовал, что грузовик под ним шевельнулся, стрелял, стрелял в него этот белогвардеец и раздробил бедро и обеспечил бессмертие...»44.

\section{Словен.:}

Rjuhin je vzdignil glavo in opozoril, da so že davno v Moskvi [...] in da čisto blizu njegastoji na podstavku kovinski človek z rahlo sklonjeno glavo in ravnodušno gleda na bulvar.

Obolelemu pesniku so šinile v glavo neke čudne misli. »Tu je zgled resnične uspešnosti...." - in Rjuhin se je zravnal na podu tovornjaka in vzdignil roko, kdo ve zakaj napadajoč žel e zn eg a moža, ki ni nikomur nič hotel, «kar koli je storil v življenju, kar koli se je zgodilo z njim, vse mu je bilo v korist, vse pripomoglo k njegovi slavi! Kaj pa je naredil? Ne gre mi v glavo... Je mar kaj posebnega vbesedah 'B u rja z megl o..’? Ne razumem!... Srečo je imel, srečo!» je mahoma strupeno sklenil Rjuhin in začutil, da je tovornjak pod njim premaknil, „tisti belogardist je ustrelil nanj in mu je zdrobil bedro, pa mu je zagotovil nesmrtnost..." ${ }^{45}$.

Хорв.:

Rjuhin je podigao glavu i vidio da je već odavno u Moskvi [...] i da nedaleko od njegastoji na postolju čovjek od metala malo naklonjene glave i ravnodušno gleda na bulevar.

Nekakve čudne misli navrle su u glavu oboljela pjesnika. «Evo primjera pravog uspjeha...» - Rjuhin je ustao u svoj svojoj visini na platformi kamiona i digao ruku napadajući mirnog čovjeka od livenog željeza - bilo kakav korak što ga je taj učinio u životu, sve se pretvaralo u njegovu slavu! A što on je to učinio? Ja ne mogu shvatiti... Zar je nešto naročito u tim riječima: 'Bu ra m a glo m...'? Ne razumijem!.. Njemu je uspjelo, uspjelo! — iznenada je bijesno pomakao - pucao je, pucao u njega onaj bjelogardijac i razmrskao mu bedro i osigurao besmrtnost...» ${ }^{46}$.

\section{Серб.:}

Rjuhin podiže glavu i zapazi da se već odavno nalazi u Moskvi [...] i da u njegovoj blizini na postolju stoji čovek od metala, jedva malo nakrenute glave i ravnodušno posmatra bulevar.

Nekakve čudnovate misli pohrliše u glavu pesnika, koji oseti da mu nije dobro. «Eto primera pravog uspeha...» I tu Rjuhin stade na platformu kamiona i poduže ruku, preteći zbog nečega tučan om čoveku, koji nikada i nikoga nije dirao. Ma šta da je uradio u životu, ma šta da mu se desilo, sve je išlo njemu $\mathrm{u}$ korist, sve je išlo u prilog njegovoj slavi! A šta je on pa uradio? Ne shvatam... Zar ima nečeg posebnog u rečima: 'Bura je maglom...' Ne shvatam... 'Imao je

${ }^{44}$ М.А. Булгаков, Собрание сочинений, т. 7 .., с. 88.

45 M.A. Bulgakov, Mojster in Margareta ..., c. 108-109.

${ }^{46}$ M.A. Bulgakov, Majstor i Margarita...1993, c. 79. 
sreće, imao!' Rjuhin najednom oseti da je kamion pod njim počeo da se pokreće, „ pucao je u njega onaj belogradejac, i razneo mu butinu, i obezbedio mu besmrtnost time...» ${ }^{47}$.

Боле.:

Рюхин вдигна глава и видя, че вече са пристигнали [...] и че съвсем близо, на постамента до него стои един метален човек, леко свел глава и вперил безразличен поглед към булеварда.

Странни мисли нахлуха в съзнанието на заболелия поет. «Ето това се казва галеник на съдбата... - Рюхин се изправи в цял ръст в каросерията на камиона и жлъчно вдигна ръка към чугунения човек, който не закачаше никого, - каквото и да е предприемел в живота си, каквото и да му се е случвало, всичко се е обръщало в негова полза и му е носело слава! А какво е направил? Не разбирам...Какво толкова има в думите: “Буря крие небесата...”? Не разбирам... Галеник, галеник! - изведнъж ядно реши Рюхин и усети, че камионът под него трепва. - Онзи белогвардеец е стрелял по него, прострелял го е в бедрото и му е осигурил безсмъртие...» ${ }^{48}$.

В комментариях к роману, составленных Евгением Яблоковым для Собрания сочинений, этот пассаж расшифровывается по нескольким позициям, начиная с сопоставления со стихотворением Владимира Маяковского Юбилейное, где лирический герой гуляет с памятником Пушкину по Москве (версия Бориса Гаспарова), и заканчивая «классовым» подходом к великому предшественнику со стороны советских поэтов ${ }^{49}$. Не каждый иностранный читатель сразу поймет, что Рюхин в порыве злобной зависти вспоминает начало пушкинского стихотворения Зимний вечер, до сих пор входящее в школьную программу, а белогвардейцем называет Жоржа Дантеса. Лишь в хорватском и болгарском переводах есть сноски (постраничная и концевая, соответственно), объясняющие, что речь идет о знаменитом московском памятнике Пушкину, в болгарском также есть пояснение к пушкинской цитате: «Буря мглою [небо кроет]» - началото на стихотворението Зимна вечер на А. С. Пушкин. («Буря мглою [небо кроет]» - начало стихотворения Зимний вечер А.С. Пушкина) ${ }^{50}$.

Без комментария практически не поддается тождественному воспроизведению и колорит, присущий сценам с пением. Из-

\footnotetext{
47 M.A. Bulgakov, Majstor i Margarita ..., 2009, c. 111.

${ }^{48}$ М.А. Булгаков, Майстора и Маргарита ..., с. 85.

${ }^{49}$ Е.А. Яблоков, Комментарии [к роману «Мастер и Маргарита»]..., с. 622 624.

${ }^{50}$ М.А. Булгаков, Майстора и Маргарита ..., с. 467.
} 
вестно, что народная песня на слова Дениса Давыдова Дума беглеца о Байкале (1858), написанная от лица бежавшего ссыльного, пережила второе рождение в период революции 1905 г., став тогда одной из массово исполняемых.

Славное море, с в я щ ен н ы й Байкал...

Славен корабль, о мулев в я бочка!..

Гей, б а р гу з и н... пошевеливай вал! -

Молодцу быть недалечко! ${ }^{1}$

В переводах эпизода с неконтролируемым исполнением этой песни сотрудниками филиала Зрелищной комиссии озеро Байкал оказывается «святым» и даже «пресвятым» вместо «священного», омуль заменяется лососем и кефалью, название байкальского ветра «баргузин», имя которому дала река Баргузин, - нейтральным «северным ветром». В хорватском переводе топоним оказался и вовсе нераспознанным, его заменяет существительное «l a đ a r» («матрос»), которое в современном языке часто имеет негативную коннотацию - человек, отличающийся вызывающим поведением (драчун, пьяница и бабник).

\section{Словен.}

Slavni Bajkal, ti sveto morje...

Slavna je ladja, lo s o s ov sod...

Hej, s everni veter... poženi val!...

Junaku daleč pluti ni... ${ }^{2}$

Серб.

Slavno je more presveti Bajkal...

Slavan je brod, bure mladica!

Hej B arguzin e... brže se kreći...

Junačina mora da je blizu! 54

Хорв.

Slavno more, sveti Bajkale...

Slavni moj brode, ribarska bačvo...

Hej l a đa r u, pokreni valove!... Junaku nije daleko!....53

Болг.

Славно море е св ещен и Байкал...

Славният кораб - каче за кефали!

Хей, баргузин, ти си сякаш заспал!

Скоро ще сме се прибрали!55

В болгарском переводе есть разъяснение слова «баргузин», а также комментарий ко всему эпизоду, заимствованный из Булгаковской энциклопедии и переведенный на болгарский язык без указания источника ${ }^{56}$.

${ }^{51}$ М.А. Булгаков, Собрание сочинений..., т. 7, с. 232.

${ }^{52}$ M.A. Bulgakov, Mojster in Margareta..., c. 238-239.

${ }^{53}$ M.A. Bulgakov, Majstor i Margarita...2009, c. 206.

${ }^{54}$ M.A. Bulgakov, Majstor i Margarita...1993, c. 255-256.

55 М.А. Булгаков, Майстора и Маргарита..., с. 216.

56 «Эпизод с хоровым кружком, поющим 'Славное море...', возможно, навеян случаем, связанным с другой ‘байкальской’ песней. 18 декабря 1933 г. 
Представленные выше наблюдения показывают, с какими трудностями сталкиваются переводчики, отважившиеся подступиться к тексту романа Macmep и Mаргарита, столь плотно насыщенному культурными ассоциациями, реминисценциями, аллюзиями, историко-культурными и бытовыми реалиями. Для успешного перенесения последних на иную культурную почву от переводчика требуется глубокое, практически профессиональное погружение в контекст воссоздаваемой эпохи (эпох), владение обширной внелитературной - страноведческой, социокультурной, этнографической - информацией об СССР и Москве времени создания романа, умение свободно ориентироваться в пространстве мировой и русской литературы, а также знание человеческой и литературной биографии русского писателя.

Если предмет, факт или явление, присутствующее в романе, не имеет аналогов в иной культуре и слова или выражения, их называющие, относятся к сегменту безэквивалентной лексики, перевод необходимо дополнить внутритекстовым пояснением или «переводческим» комментарием, объясняющим или уточняющим эти реалии или разъясняющим значение непонятных слов, это касается изданий, ориентированных как на массового, так и на «продвинутого» читателя вне зависимости от поставленной эдикционной задачи. Ведь разрыв между произведением и его адресатом, по Дмитрию Лихачеву, «параллакс», связанный с сокращением активного культурного фонда читателя, сегодня только увеличивается. С учетом особенностей поэтики Булгакова особую трудность представляет передача внеязыкового фона - аллюзий, намеков, реминисценций, подтекста. Здесь, на наш взгляд, в идеале требуется полноценный справочный аппарат (биобиблиографическая информация, постранич-

Е.С. Булгакова оставила в дневнике следующую запись: «...Поздно вечером Рубен Симонов потащил нас к себе. Там были еще и другие вахтанговцы, было очень просто и весело. Симонов и Рапопорт дуэтом пели По диким степям Забайкалья... (Один из поющих будто бы не знает слов, угадывает, вечно ошибается: 'навстречу - родимый отец...' [поправляется: мать!] и т.д.). Обратно Симонов вез нас на своей машине - по всем тротуарам - как только доехали!» У Коровьева-Фагота хор поет песню слаженно и правильно, только никак не может остановиться. То, что пьяный руководитель Театра имени Евг. Вахтангова Р.Н. Симонов (1899-1968) благополучно довез писателя и его жену до дому, могло быть расценено Е.С. Булгаковой как покровительство Бога или дьявола». Булгаковская энциклопедия, https://www.bulgakov. $\mathrm{ru} / \mathrm{k} /$ fagot/3 (09.02.2019). 
ные примечания, профессиональный затекстовый комментарий специалистов). Лишь в этом случае художественный мир булгаковского романа будет максимально приближен иноязычной читательской аудитории.

И, главное, переводчик, взявшийся перевести роман $\mathrm{Ma}$ стер и Маргарита, помимо блестящей эрудиции, пытливости и упорства должен стремиться отождествить свое «я» с миропониманием и мироощущением Булгакова и только потом искать краски для воплощения его произведения на своем языке.

\section{БИБЛИОГРАФИЯ}

Belobrovceva, Irina, Kul'yus, Svetlana. Roman "Master i Margarita": kommentariy. Tallinn: Argo, 2006 [Белобровцева, Ирина, Кульюс, Светлана. Роман "Мастер и Маргарита": комментарий. Таллинн: Argo, 2006].

Bulgakov, Mikhail. Majstor i Margarita. Beograd: IP Book, 2009.

Bulgakov, Mikhail. Majstor i Margarita. Rijeka: Andromeda, 1993.

Bulgakov, Mikhail. Majstora i Margarita. Sofiya: Damyan YAkov, 2012 [Булгаков, Mikhail. Майстора и Маргарита. София: Дамян Яков, 2012].

Bulgakov, Mikhail. Mojster in Margareta. Ljubljana: Cankarjeva zalozhba, 1971.

Dyurishin, Dioniz. Teoriya sravnitel'nogo izucheniya literatur. Traslated by I.A.Bogdanova. Moskva: Progress, 1979. [Дюришин, Диониз. Теория сравнительного изучения литератур. Перевод И.А. Богдановой. Москва: Прогресс, 1979].

Lunkova, Natalya. "Problema perevodcheskogo kommentariya (na primere perevoda romana 'Master i Margarita' na bolgarskiy yazyk)." Mikhail Bulgakov i slavyanskaya kul'tura. Moskva: Sovpadenie, 2017 [Лунькова, Наталья. “Проблема переводческого комментария (на примере перевода романа 'Мастер и Маргарита' на болгарский язык).” Михаил Булгаков и славянская культура. Москва: Совпадение, 2017].

Moroz, Narkiza Abrikovna. "Adekvatnaya peredacha realij russkoy kul'tury v khudozhestvennom perevode." Molodoy uchenyy 2015 no. 15 [Мороз, Наркиза Абриковна. “Адекватная передача реалий русской культуры в художественном переводе.” Молодой ученый 2015 по. 15].

Revzin, Isaak, Rozencveyg, Viktor. Osnovy obshchego i mashinnogo perevoda. Moskva: Vysshaya shkola, 1964 [Ревзин, Исаак, Розенцвейг, Виктор. Основы общего и машинного перевода. Москва: Высшая школа, 1964].

Shat'ko, Evgenya. "Specificheskiye 'sovetskiye`i russkiye realii v perevodakh romana 'Master i Margarita' (na materiale perevodov V. Flaker i M. Cholicha)." Mihail Bulgakov i slavyanskaya kul'tura. Ed. Lun'kova, N.A., Starikova, N.N., Yablokov E.A. Moskva: Sovpadeniye, 2017. [Шатько, Евгения. "Специфические 'советские' и русские реалии в переводах романа 'Мастер и Маргарита' (на материале переводов В. Флакер и М. Чолича).” Михаил Булгаков и славянская культура. Ред. Лунькова, Н.А., Старикова, Н.Н., Яблоков, Е.А. Москва: Совпадение, 2017]. 
Smirnov, Yuriy. “Teatr i teatral'noe prostranstvo v romane M.A. Bulgakova 'Master i Margarita”. Mihail Bulgakov: 'Etot mir moy...'. T. 1. Sankt Peterburg: RIII, 1993 [Смирнов, Юрий. “Театр и театральное пространство в романе М.А. Булгакова 'Мастер и Маргарита.” Михаил Булгаков: ‘Этот мир мой...'. Т. 1. Санкт-Петербург: РИИИ, 1993].

Starikova, Nadezhda. "Realii sovetskoy Moskvy v slovenskom perevode romana 'Master i Margarita' (k probleme konteksta)." Mikhail Bulgakov i slavyanskaya kul'tura. Ed. Lun'kova, N.A., Starikova, N.N., Yablokov E.A. Moskva: Sovpadeniye, 2017 [Старикова, Надежда. "Реалии советской Москвы в словенском переводе романа 'Мастер и Маргарита' (к проблемеконтекста).” Михаил Булгаков и славянская культура. Ред. Лунькова, Н.А., Старикова, Н.Н., Яблоков, Е.А. Москва: Совпадение, 2017].

Toury, Gideon. "Descriptive Translation Studies - and beyond." Benjamins Translation Library 1995 no. 4.

Yablokov, Yevgeniy Aleksandrovich. "Kommentarii [k romanu 'Master i Margarita']." Bulgakov, Mikhail. Sobranie sochineniy. Moskva: AST 2007-2011. [Яблоков, Евгений Александрович. “Комментарии [к роману „Мастер и Маргарита'].” Булгаков, Михаил. Собрание сочинений. Москва: АСТ, 2007-2011].

Natalia Łuńkowa, Nadieżda Starikowa, Jewgienija Szat'ko

POWIEŚĆ MISTRZ I MAEGORZATA:

TRUDNOŚCI W TŁUMACZENIU SOWIECKICH REALIÓW

(NA PRZYKŁADZIE JĘZYKÓW POŁUDNIOWOSŁOWIAŃSKICH)

Streszczenie

W artykule analizowane są sposoby tłumaczenia na języki południowosłowiańskie (bułgarski, serbski, chorwacki, słoweński) słów i zwrotów określających przedmioty, zjawiska i obiekty charakterystyczne dla życia, codzienności i kultury mieszkańców Moskwy pierwszych dziesięcioleci władzy radzieckiej. Skomplikowanie artystycznej struktury powieści, połączenie w niej wielu tradycji kulturowych, historycznych i religijnych, współwystępowanie różnych językowo-stylistycznych konwencji stawia przed tłumaczami bardzo trudne zadanie. Jednym z niezbędnych warunków prawidłowego jego rozwiązania staje się obecność w przekładzie różnego rodzaju sposobów objaśniania trudnych do zrozumienia w kulturze docelowej elementów.

Natalia Lunkova, Nadezhda Starikova, Evgenia Shatko

THE NOVEL THE MASTER AND MARGARITA:

THE DIFFICULTIES OF TRANSLATING SOVIET REALIAS (ON THE EXAMPLE OF SOUTH SLAVIC LANGUAGES)

Summary

The article deals with the ways of transferring words and phrases naming things, phenomena, and objects typical for life, daily routine and culture of the Muscovites 
during the first decades of Soviet power, used for translation of the novel "The Master and Margarita" into South Slavic (Bulgarian, Serbian, Croatian, Slovenian) languages. The complexity of the novel's artistic structure, the combination of several cultural, historical and religious traditions, stylistic and linguistic layers, possess a very difficult task for translators. One of the necessary conditions for its solution is the presence in the translated edition a reference device (reference comments) explaining difficult passages. 